\title{
頭頸部癌化学放射線療法中に発症した重篤な副作用
}

- bacterial translocation と reversible posterior leukoencephalopathy-

$\begin{array}{lll}\text { 橘 } & \text { 伸哉1) } \cdot \text { 寺尾 } \quad \text { 元 }^{1)} \cdot \text { 勝野 雅弘 }{ }^{2)} \\ \text { 竹村 } & \text { 栄毅 } 3) \cdot \text { 三邊 武幸1) }\end{array}$

\section{A Case of Reversible Posterior Leukoencephalopathy Syndrome which Developed during Chemoradiotherapy for Head and Neck Cancer: the Involvement of Bacterial Translocation was Considered}

\author{
Shinya Tachibana, Hajime Terao and Takeyuki Sanbe \\ (Showa University Fujigaoka Hospital) \\ Masahiro Katsuno \\ (Odawara City Hospital) \\ Hideki Takemura \\ (Yokohama Rosai Hospital)
}

Combination therapy such as chemotherapy and radiotherapy is often chosen, depending on the case, for head and neck cancer in view of the preservation of potency. However, on the other hand, it is necessary to note the onset of therapeutic side effects.

The patient was a 35-year-old woman. During chemoradiotherapy for mesopharyngeal carcinoma, she suddenly developed shock and multiple organ failure, requiring intensive treatment. She also developed reversible central nerve symptoms during the course.

The involvement of bacterial translocation was thought to be the cause of shock, and the reversible central nerve symptoms were considered to be a pathological condition, known as reversible posterior leukoencephalopathy syndrome. We discuss these conditions on the basis of the clinical features, and the process that led to diagnosis in this case.

Key words : reversible posterior leukoencephalopathy syndrome (RPLS), chemoradiotherapy, bacterial translocation

はじめに

中咽頭癌に対して行った化学放射線療法の際に, 敗血 症性ショックに陥り, 可逆性の中枢神経症状を呈した症 例を経験した. 敗血症性ショックの原因として, bacterial translocationの関与が考えられ, 可逆性の中枢神経症状は reversible posterior leukoencephalopathy syndrome と呼ば れる病態と思われた。

症例

1）昭和大学藤が丘病院耳鼻咽喉科

2）小田原市立病院耳鼻咽喉科

3）横浜労災病院耳鼻咽喉科 
主訴：咽頭痛.

既往歴・家族歴：特記すべきことなし。

現病歴: 咽頭痛にて 2004 年 4 月 28 日当科を初診した. 初診時, 左口蓋扁桃に赤色隆起性の病変を認め, 擦過細 胞診を行ったところ class Vであったため, 精查加療目的 で 5 月 28 日入院となった. 入院後, 組織診および頸部造 影 CT スキャンを施行し, 中咽頭高分化型扁平上皮癌 （T2N1M0）と診断した.

経過：頭頸部扁平上皮癌 Stage III, IV に対する当科の 化学放射線療法プロトコールを図 1 に示す. 化学療法と して TS- $1120 \mathrm{mg}\left(80 \mathrm{mg} / \mathrm{m}^{2}\right)$ を 14 日間内服し, 内服開
始から 4 日目に Nedaplatin $150 \mathrm{mg}\left(90 \mathrm{mg} / \mathrm{m}^{2}\right)$ を点滴投 与する. TS-1 内服終了後, 14 日間を休薬期間とする. 放 射線治療は 1 日 $1.2 \mathrm{~Gy} \times 2$ 回で週 5 日 3 週間，化学療法 と同時に開始する.

2004 年 6 月 1 日より 28 日まで 1 クールを施行．その 後, 採血や尿検查, 胸部 X 線にて全身状態に問題のない ことを確認し， 7 月 5 日から 2 クールを開始した。

7 月 11 日早朝, 突然の腹痛と 41.5 度の発熱を認めた。 収縮期血圧が $80 \mathrm{mmHg}$ 一低下したため, dopamine hydrochloride, dobutamine hydrochloride, norepinephrine を投与したが，昇圧できず竹には意識レベルも低下

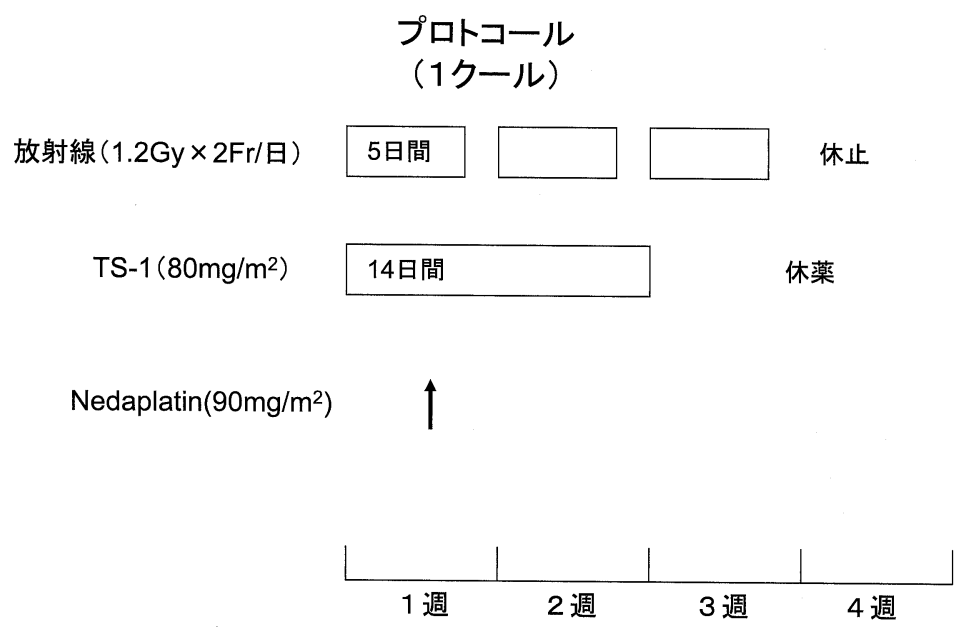

図 1 当科での治療方針

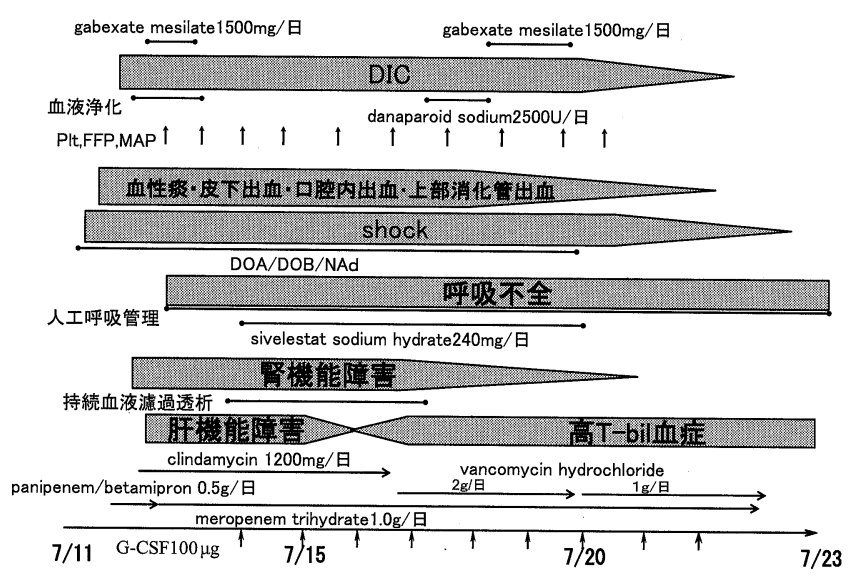

a

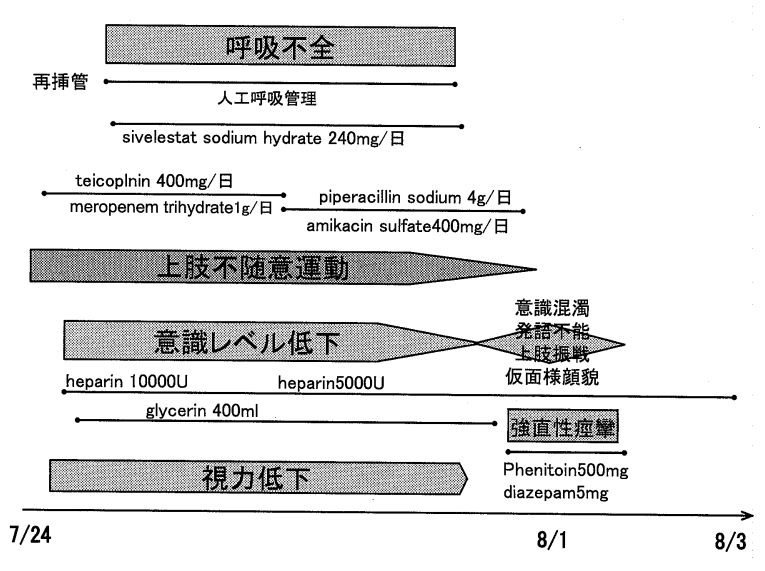

b

図 $2 \mathrm{a}$ : 治療経過（その 1)

$\mathrm{b}$ ：治療経過（その 2) 


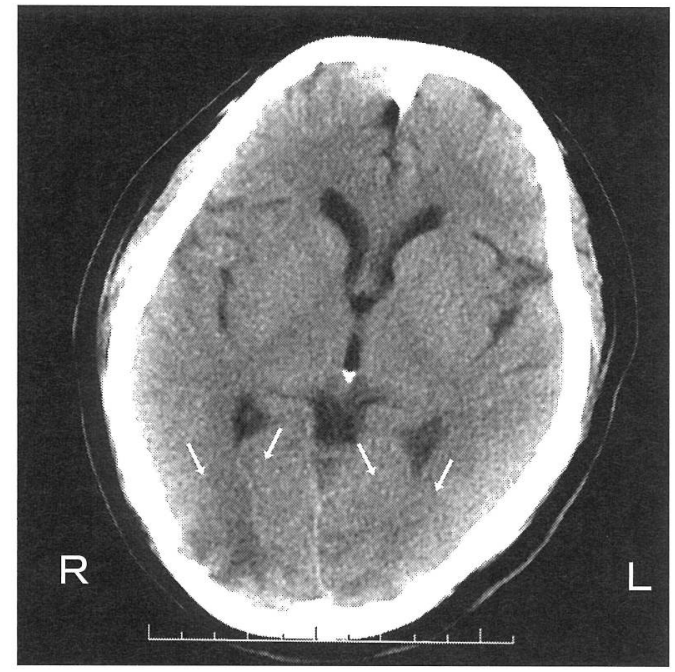

図 3 視力障害発症時の頭部単純 CT 画像 不明瞭ながら両側後頭葉に低吸収域を認める (矢印)。

（GCS E1M4V2）した.

同日夜には血圧 $62 / 40 \mathrm{mmHg}$ まで低下し，それに伴う 急性腎不全 (BUN $30.0 \mathrm{mg} / \mathrm{dl}$, Cre $2.0 \mathrm{mg} / \mathrm{dl}$ ) ・肝不全 （GOT 395 U/1, GPT 222 U/1）を発症したため，ICU での 管理を行った。

治療経過を図 2 （a， b）に示す．急性腹症によるショッ クと考光, 腹部単純 $\mathrm{X}$ 線, 腹部超音波・経臸超音波, 腹 部 CT，上部および下部消化管内視鏡を施行したが明ら かな急性腹症の原因と思われる所見は認めなかった。血 液培養から Serratia marcescens が検出され, 敗血症性 ショックと確定診断した。 DIC, 肝不全, 腎不全, 呼吸 不全に対し, 抗生剤 (panipenem/betamipron から, clindamycin と meropenem trihydrate 一变更), 昇圧剂 (dopamine hydrochloride, dobutamine hydrochloride, norepinephri-

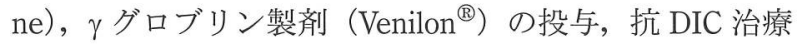
(gabexate mesilate, danaparoid sodium), 透析治療, 大量 の輸血，鎮静下人工呼吸管理，呼吸不全治療（sivelestat sodium hydrate）を行った。 7 月 23 日（ICU 入室後 12 日） に, 人工呼吸器を離脱, 拢管した。

しかし 7 月 24 日（ICU 入室後 13 日）夜，急激な視力 低下を訴光, 数時間のうちに視力は両眼之も光覚弁と なった。頭部 CT, MRI を施行したところ, 両側後頭葉 に CT で低吸収域，MRI では T2 強調画像，FLAIR 画像 いずれも高信号の部分を認め，虚血と思われた（図 3, 4a，b，c）。再度意識レベルも低下し（GCS E3M4V3），
呼吸状態も悪化したため, 再扱管し人工呼吸管理とした。 脳梗塞に準じ，抗凝固薬（heparin），浸透圧利尿薬 (glycerin) の投与を行った。 7 月 30 日（ICU 入室後 19 日）には呼吸状態と視力が改善し，人工呼吸器を離脱し 抜管となった。拢管時, 軽度の意識混濁 (GCS E3V3M5), 上肢振戦, 仮面様顔貌などの神経症状がみられた。 7 月 31 日, 強直性痓攣が数回出現したため, 抗㾏攣剂 (phenitoin，diazepam）を投与し経過観察したところ，㾏攣は 消失し，意識レベルも改善した（GCS E4V5M6）。頭部 MRI を施行したところ, 以前みられた後頭葉の病変は消 失していた（図 $5 \mathrm{a}, \mathrm{b}$ )。その後全身状態は安定し，8月 3 日（ICU 入室後 23 日），一般病棟へ帰室した。

帰室後, 放射線治療を 9 月 14 日まで計 $69.6 \mathrm{~Gy}$ 施行 し，9月 22 日に退院した。肉眼的には原発腫瘍および頸 部リンパ節は消失していた. 治療效果判定目的にて 10 月 28 日, 全身麻酔下で左扁桃摘出術を行い, 病理学的にも 癌の残存は認めなかった。 11 月 2 日退院し，現在は外来 で経過観察中である。

\section{考察}

1: bacterial translocation

本症例では化学放射線療法中に，急激な腹部症状から 敗血症性ショックを発症した。各種検索にても明らかな 感染巣は認めえず, 腸内細菌でもある Serratia marcescens が血中から検出されたことより, bacterial translocation の 関与が考光られた。

bacterial translocation とは, 本来腸管内に存在する細菌 が，何らかの原因で晹管壁を通って腸管以外の臓器や組 織に移行する現象であり，1979 年に Berg ら ${ }^{11}$ により提 唱された概念である。加えて, 1990 年 Alexander ら²) が 生菌のみでなくエンドトキシンやその他炎症惹起物質を 含めて腸管臟器以外に移行する現象を microbial translocation と称した。 現在ではこれらも含めて bacterial translocation と呼ばれることが多い。

bacterial translocation は, 臨床的には, 外科手術後や急 性膵炎, 熱傷, 多発外傷などの高度侵襲時に集中治療室 で経験することが多く,感染源の特定できない敗血症や， それに続発した多臟器不全などの原因として注目されて いる. bacterial translocation が起こる要因としては腸管粘 膜の脆弱化, 宿主の免疫能低下, 腸管細菌叢の变化のう ち 1 つ以上が関与すると考光られており ${ }^{3)}$ ，これらを起 こしらる状態であれば，前述の要因以外にも，手術や 


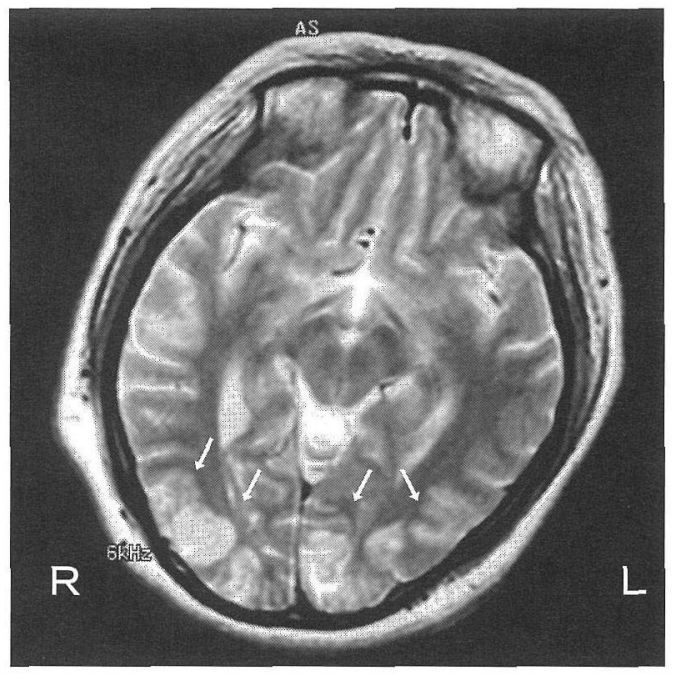

a

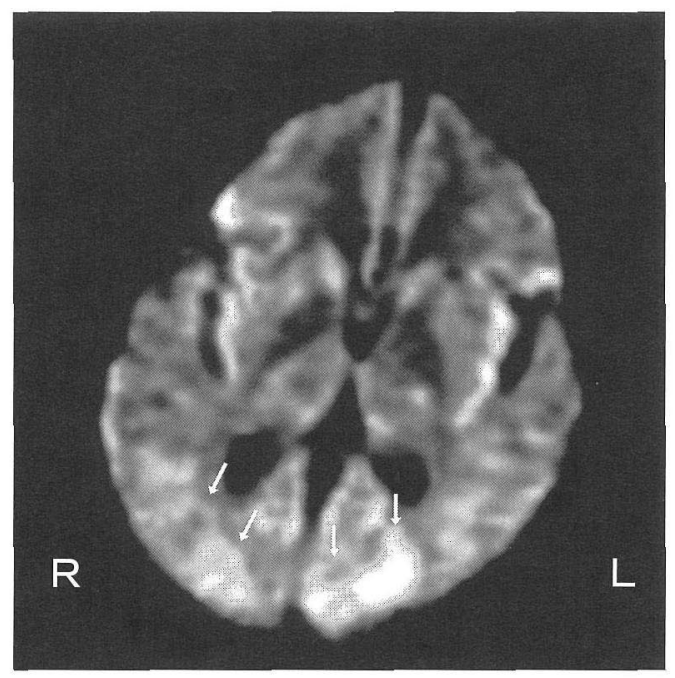

c

ショックによる腸管虚血，抗癌剂・免疫抑制剂投与，イ レウスによる腸管内容の停滞や腸管蠕動の低下，広域抗 生剂の投与や中心静脈栄養による腸内細菌叢の变化な ど, bacterial translocation の起こりえる状況は多岐にわた ると思われる。

診断は，直接的診断と間接的診断に分けられる。直接 的診断とは，開腹手術の際に腸間膜リンパ節を採取し， その培養によりリンパ節中に腸内細菌を証明する方法で ある. O’boyle ら ${ }^{4)}$ は，開腹術症例で腸間膜リンパ節を採 取培養し, 腸内細菌が検出された頻度は 448 例中 69 例 （15.9\%）と報告している。

一方，間接的診断は，血液培養で腸管由来の細菌が陽

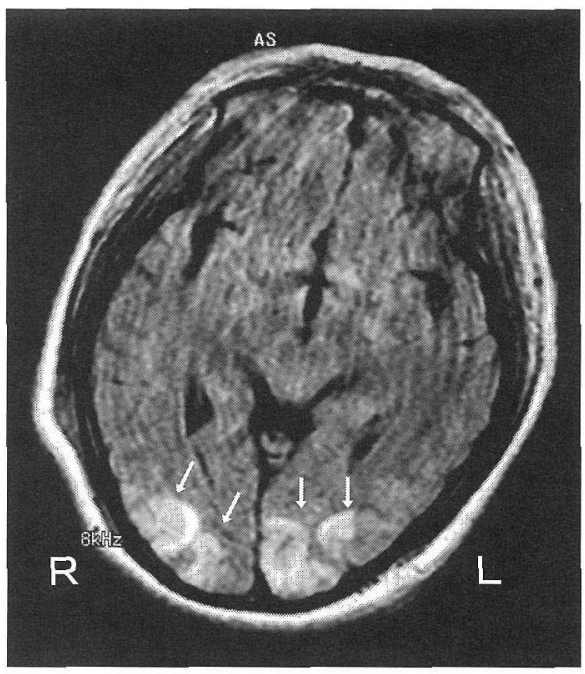

b

図 $4 \mathrm{a}$ : 視力障害発症時の MRI T2 強調像、両側後頭葉に高 信号部分（矢印）を認める。

$\mathrm{b}$ : 視力障害発症時の MRI FLAIR 像. 両側後頭葉に高 信号の部分（矢印）を認める.

$\mathrm{c}$ : 視力障害発症時の MRI 拡散強調画像. 後頭葉は高 信号を呈している (矢印)。

性であること，血中エンドトキシンや血中サイトカイン (IL-1，IL-6，TNF，PGE など）の高值から bacterial translocation の存在を証明しようとするものである.間接的方 法で bacterial translocation と診断される割合は，織田 ${ }^{5)}$ によれば多臟器不全 354 例のうち，10.5\%であったとし ている。また Goris ら ${ }^{6)}$ は，敗血症による多臓器不全で 死亡したと考えられる症例の 30\%以上において，明らか な感染巣を認めなかったとされ, bacterial translocation が 原因であった可能性を指摘している。なお現在では新し い診断法として，PCR 法による末梢血からの腸内細菌の 証明が試みられている。検出感度や特異度が高いこと や，数時間で結果が得られることからら臨床応用が期待さ 


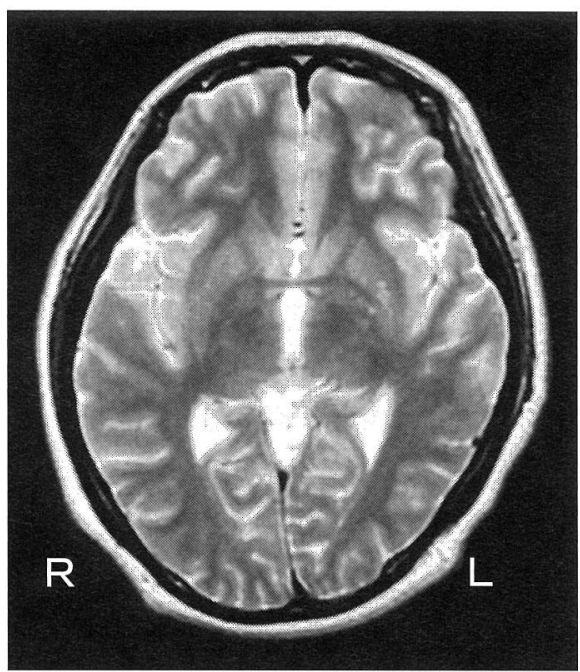

a

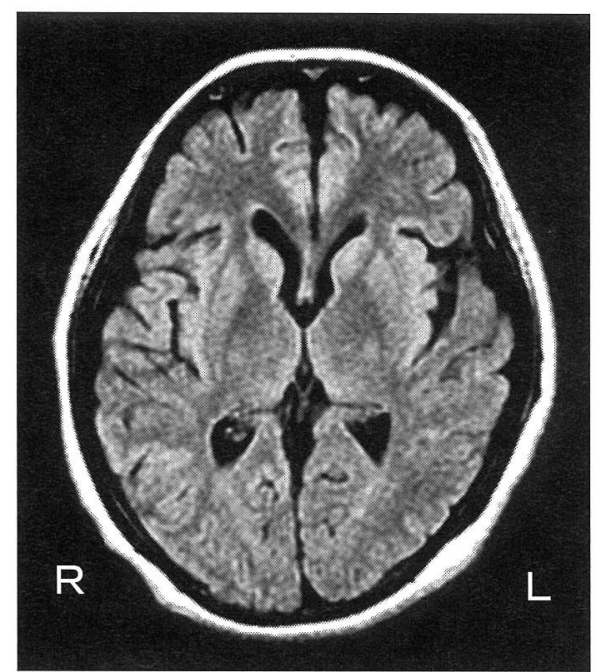

b

図 $5 \mathrm{a}$ ：治療後 MRI T2 強調像. 病変を認めない.

b : 治療後 MRI FLAIR 像. 病変は消失している.

れる7).

本例において bacterial translocation の関与が考えられ た理由として，(1)体内に留置していたカテーテル類は化 学療法に使用していた静脈末梢ルート1本であり, カテー テル先端の細菌培養は陰性であった(2)血液中から腸内細 菌である Serratia marcescens が検出された(3)消化管疾患・ 婦人科疾患の既往もなく, ショック発症後の各種検査に て腹部に感染巣が見出せなかったことが挙げられる。な お, 同時期同じ病棟において他の患者からも 1 名 Serratia marcescens が検出されていたが，遺伝子学的検索にて本 例のものと異なることを確認している.7月 11 日発症以 前に消化器症状もなく, 易感染を呈するような合併症も なかった，化学療法（TS-1, Nedaplatin）によって腸管 に bacterial translocation を許す環境がもたらされていた と考えた。

2 : reversible posterior leukoencephalopathy syndrome

ショックに続発した意識障害, 視力低下などの中枢神 経症状の病態として, reversible posterior leukoencephalopathy syndrome が考えられた。

reversible posterior leukoencephalopathy syndrome は，1996 年に Hinchey ら ${ }^{8)}$ により提唱された疾患概念で あり, 頭痛・意識障害・視力障害・痤戀などを呈し, 画 像上，頭部後半を中心とした病変がみられるものの，治 療によりいずれも可逆的な経過をとるのが特徴である.
表 1 に示すように ${ }^{9)}$, 種々の疾患や病態に伴って起こり, 血管内皮細胞障害・腎機能障害・体液貯留傾向などの関 与が考えられている。画像所見では，頭部 CT で低吸収 域, MRI T1 強調画像で若干の低信号, T2 強調画像およ びFLAIR 画像で高信号を呈する病変が, しばしば左右対 称性・多発性に，大脳半球後部皮質を中心として広がる ことが特徵とされる.

発症機序について, 富田ら 10$)$ は次の 2 説を挙げている. 血管攣縮による細胞虚血が cytotoxic edema(細胞性浮腫)

表 1 reversible posterior leukoencephalopathy syndrome の原因

・急激な血圧上昇

- 高血圧性脳症

- 尿毒症（急性系球体腎炎, 溶血性尿毒症症候群, 血栓性血 小板減少性紫斑病，紫斑病性腎炎）

・膠原病（SLE，RA, PN，シェーグレン症候群など）

-子痭, 子痭前症

- 癌化学療法, 免疫抑制薬

• cisplatin, MTX, Ara-C, 5-FU, tegafur など

- cyclosporine A, tacrolimus, IFN

・急激なへマトクリット上昇

・濃厚赤血球, erythropoietin

- $\gamma$-globlin 大量療法

- その他

骨髄移植, コカイン中毒, ヘロイン中毒など

誘因不明 
を生じて起こるという vasospasm theory と，脳血管の自 動調節能が破綻し脳細動脈が受動的に拡張することで, 血漿成分が血管外に漏出し vasogenic edema（血管性浮 腫）を生じるとされる vasodilatation theory である.

reversible posterior leukoencephalopathy syndrome にお いて, 画像異常が一部残存したり, 画像異常の改善に時 間がかかったりする症例や，また程度の異なる病変が混 在する症例の存在が知られてきた ${ }^{8110)} \sim 12$. reversible posterior leukoencephalopathy syndrome の病変の描出に は MRI 拡散強調画像や apparent diffusion coefficient 画像 が有用とされている ${ }^{12)}$. 細胞性浮腫の部位は拡散強調画 像で高信号, apparent diffusion coefficient 画像では低信号 を呈するといわれ一般に不可逆的な経過をとる。一方， 血管性浮腫の部位は拡散強調画像で等信号から軽度高信 号を, apparent diffusion coefficient 画像では高信号を呈 し, 治療に反応し可逆的な変化をとることが報告されて いる1013). また, reversible posterior leukoencephalopathy syndrome の画像異常が一部残存したり, 画像異常の改善 に時間がかかったりする症例や, 程度の異なる病変が混

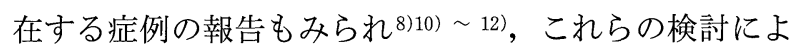
り, reversible posterior leukoencephalopathy syndrome $の$ 主たる病態が血管性浮腫であることが明らかになりつつ ある.すなわち, 拡散強調画像で等信号から軽度高信号, また apparent diffusion coefficient 画像で高信号を呈する 病変は, 血管性浮腫を反映し可逆性で, reversible posterior leukoencephalopathy syndrome を示唆する.

reversible posterior leukoencephalopathy syndrome の臨 床症状は, 種々の程度の痓攣・頭痛・意識障害・視力障 害などで, 特異的なものはない. しかし後頭部領域に病 変が存することが多く，そのため皮質盲（両側後頭葉の 障害により視覚を喪失した状態）が視覚異常として特徴 的である ${ }^{8)}$. 後頭部領域に好発する理由は, 椎骨脳底動 脈系の交感神経支配が内頸動脈系にくらべ弱く, そのた め脳血管の自動調節能が比較的破綻しやすいためと考え られている14).

治療は基本的に対症療法で, 原因と考えられる薬剤が あれば中止, 高血圧や痤攣に対して降圧剂, 抗痤攣薬, 抗脳浮腫薬などを投与する. ステロイドが有効であった との報告もあるが15)，ステロイド使用中に reversible posterior leukoencephalopathy syndrome を発症した例も

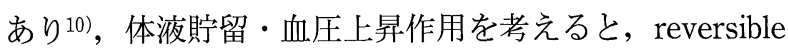
posterior leukoencephalopathy syndrome に対するステロ
イド使用は十分留意すべきだとされる12)。

本症例に reversible posterior leukoencephalopathy syndrome が起こった背景として, 化学療法および敗血症 性ショックが挙げられる. 本例での敗血症性ショックに 伴う多藏器不全は重篤で, 昇圧剤の 3 剂投与 (dopamine hydrochloride, dobutamine hydrochloride, norepinephrine) にても血圧維持が困難な時期があったこと, DIC による 出血傾向とそれに伴う出血に対し, 多くの輸血を余儀な くされたこと(延べ輸血量は新鮮凍結血漿 32 単位, 濃厚 赤血球 20 単位, 血小板 90 単位にのぼった), また敗血症 に対しアルブミン製剤， $\gamma$ グロブリン製剤などの投与も 行っている. 大量輸血後に発症した reversible posterior leukoencephalopathy syndrome の報告もあることから ${ }^{16)}$, ショックによる循環虚脱状態に, これら高張性の物質が 断続的あるいは持続的に投与されたことは増悪因子と なったであろう。また，急性腎不全により S-1 および Nedaplatin の単独あるいは相互作用による血管内皮細胞 障害がもたらされた可能性も考えられる.

文献的に抗癌剤による一過性脳症を検索してみると, 使用薬剂による分類が散見された ${ }^{17)}$. 近年の画像診断に 伴って, 過去の報告の中でも, 改めて reversible posterior leukoencephalopathy syndrome と分類することが妥当で ある症例も存在する ${ }^{18)}$. 現在脳症の分類法は, 複数存在 するが, 病態を反映する MRI 画像所見の特徴から分類す ることが妥当であると思われた。

\section{まとめ}

頭頸部癌化学放射線療法施行中に重篤な副作用をきた し救命しえた 1 例を経験した. 敗血症性ショックの原因 として，使用した抗癌剤により引き起こされた bacterial translocationが考えられた.それに続いて発症した意識障 害・痓攣・視力障害・振戦などの一過性の中枢神経症状 は reversible posterior leukoencephalopathy syndrome に よって引き起こされていた.

なお本論文の要旨は第 67 回耳鼻咽喉科臨床学会 $(2005$ 年 7 月9日, 松山）で口演した.

\section{参考文献}

1) Berg RD and Gaelington $\mathrm{AW}$ : Translocation of certain indigenous bacteria from the gastrointestinal tract to the mesenteric lymph nodes and other organs in a gnotobiotic mouse model. Infect Immun $23: 403 \sim$ 411, 1979. 
2) Alexander JW, Boyce ST, Babcock GF, et al. : The process of microbial translocation. Ann Surg $212: 496 \sim 510,1990$.

3) Berg $\mathrm{RD}:$ Bacterial translocation from the gastrointestinal tract. J Med $23: 217 \sim 244,1992$.

4) O'boyle CJ, MacFie J, Mitchell CJ, et al. : Microbiology of bacterial translocation in humans. Gut $42: 29 \sim 35,1998$.

5）織田成人：MOF にお汸 bacterial translocation の実態とそ の対策. 日腹部救急医会誌 $23: 491 \sim 497,2003$.

6) Goris RJ, te Boekhorst TP, Nuytinck JK, et al. : Multiple-organ failure. Generalized autodestructive inflammation. Arch Surg $120: 1109 \sim 1115,1985$.

7）辻本広紀：Bacterial Translocation の新しい診断法と対策. ICU と CCU $27: 11 \sim 19,2003$.

8) Hinchey J, Chaves C, Appignani B, et al. : A reversible posterior leukoencephalopathy syndrome. N Engl J Med 334:494 500, 1996.

9) 廣瀬隆一 : reversible posterior leukoencephalopathy syndrome. Medical Practice $20: 1015 \sim 1018,2003$.

10）富田美佳, 高梨潤一, 小林和彦, 他：Reversible posterior leukoencephalopathy syndrome を呈した 4 症例の検討. 脳と 発達 $33: 426 \sim 429,2001$.

11) Kwon S, Koo J and Lee $S$ : Clinical spectrum of reversible posterior leukoencephalopathy syndrome. Pediatr Neurol 24 : $361 \sim 364,2001$.

12) Ay H, Buonanno FS, Schaefer PW, et al. : Posterior leukoencephalopathy without severe hypertension: utility of diffusion- weighted MRI. Neurology $51: 1369 \sim 1376,1998$.

13）鳥海善貴, 金井理恵, 木村正彦, 他：悪性リンパ腫の化学 療法中に reversible posterior leukoencephalopathy syndrome をきたした女児例. 日小児会誌 $108: 412 〜 417 ， 2004$.

14) Schwartz RB, Bravo SM, Klufas RA, et al. : Cyclosporine neurotoxicity and its relationship to hypertensive encephalopathy: CT and MR findings in 16 cases. AJR Am J Roentgenol 165 : $627 \sim 631,1995$.

15) Honkaniemi J, Kahara V, Dastidar P, et al. : Reversible posterior leukoencephalopathy after combination chemotherapy. Neuroradiology $42: 895 \sim 899,2000$.

16）小野政徳, 田中 淳, 玉田 裕, 他：大量輸血を伴う術後 に発症したRPLS (Reversible Posterior Leukoencephalopathy Syndrome）の 1 例. 日産婦東京会誌 $51: 286 \sim 290,2002$.

17）華岡 肇，窪田哲昭，松井和夫，他：5-FU 投与による大脳 白質脳症の 1 症例. 耳鼻臨床 補 $109: 161 \sim 163,2002$.

18）大場郁子, 丹治宏明, 清水 洋 : reversible posterior leukoencephalopathy syndrome (RPLS) の 1 例. 仙台病医誌 24: $161 \sim 166,2004$.

原稿受付：平成19年 2 月 19 日

原稿採択：平成19年 4 月 12 日

別刷請求先 : 橘 伸哉

₹211-8510 神奈川県川崎市中原区木月住吉町1-1

関東労災病院耳鼻咽喉科 